Gunārs Kūtris, Mg. iur.

Latvijas Universitātes Juridiskā fakultāte, Latvija

\title{
MANTAS KONFISKĀCIJA UN NEVAINĪGUMA PREZUMPCIJA
}

\section{CONFISCATION AND PRESUMPTION OF INNOCENCE}

\begin{abstract}
Summary
The law provides for the seizure (confiscation) of property if its criminal origin has been proven. It is also possible to seize the presumed proceeds of crime. In these proceedings, state is entitled to require a person to prove the source of the acquisition of property, because it does not affect the issue of the person's fault. It would be risky to impose an obligation on a person in criminal proceedings to prove the origin of his or her property, otherwise, it would mean suggesting that the property is of a criminal origin and that the person is criminally punishable for the laundering of such property. It would be a gross violation of the principle of presumption of innocence.
\end{abstract}

Atslēgvārdi: konfiskācija, nevainīguma prezumpcija, pierādī̌anas pienākums

Keywords: confiscation, presumption of innocence, burden of proof

\section{Ievads}

Ikviens cilvēks brīdī, kad tiek iesaistīts kriminālprocesā, ir nepatīkami pārsteigts, jo apzinās, ka viņa dzīvē radušies papildu apgrūtinājumi. Kaut vai liecinieka statusā - arī tad būs jāierodas noteiktā vietā un laikā, lai sniegtu liecību, dažkārt varētu uztraukties, vai liecības sniegšana neradīs kādus draudus. Tomēr visbūtiskākos tiesību ierobežojumus kriminālprocess rada personai, kurai ir tiesības uz aizstāvību, proti, personai, par kuras iespējami izdarīto noziedzīgo nodarījumu ir uzsākts konkrētais kriminālprocess.

No vienas puses, sabiedrības pamatotā vēlme dzīvot drošibā prasa, lai būtu efektīvas metodes cīṇai pret likumu pārkāpējiem. Tas nenoliedzami ir saistīts ar "neērtībām" personai, par kuras darbībām process notiek. No otras puses, tiesiskai valstij ir jāapzinās, ka ne jebkura metode ir attaisnojama ar sasniedzamo mērk̦i. Gan likuma radītājam, gan tā piemērotājam ir svarīgi izvērtēt piel̦aujamā tiesību ierobežojuma samērīgumu.

Patlaban ìpaši aktuāls Latvijā un arī pasaulē ir jautājums par iespējām konfiscēt noziedzīgi iegūto mantu, jo, nenoliedzami, finansējuma atṇemšana noziedzīgai darbībai vai tās dēḷ gūtā labuma atṇemšana ir nozīmīgs trieciens pašai noziedzībai.

Juristu diskusijas ir par samērīguma robežu starp vēlēšanos konfiscēt jebko, kā legālā izcelsme nav droši zināma, un cilvēka pamattiesībām. Eḷı ugunī papildus pielej populistisku (sarunvalodā precīzāks apzīmējums būtu - prastu) politiķu un masu 
mediju tendence nevēlamu / nepatîkamu cilvēku l̦oti ātri nosaukt par vainīgu jau pēc pirmās kratī̌sanas vai aizturēšanas (piemēram, publiski izteikts pārmetums, kāpēc cilvēks vēl nav atlaists no darba). Izpratne par cilvēktiesībām paliek tikai lozungiem. Aizmirstot, ka pavisam nesen - 2018. gada septembrī - tika papildināts Kriminālprocesa likums (turpmāk arī KPL), lai uzsvērtu un nostiprinātu konkrētus nevainīguma prezumpcijas aspektus. ${ }^{1}$

Tātad aktualitāte: kā pēc iespējas ātrāk un efektīvāk konfiscēt patiešām noziedzīgi iegūto un vienlaikus nodrošināt un aizsargāt cilvēka pamattiesības - nevainīguma prezumpciju. Vai saistībā ar mantas konfiskāciju šis kriminālprocesa princips pastāv? Ja valsts prezumē mantas izcelsmi kā noziedzīgu, vai personai var uzlikt kādu pierādīšanas pienākumu? Vai, apsūdzot personu par noziedzīgi iegūtu līdzekḷu legalizāciju, drīkst personai uzlikt pienākumu pierādīt pretējo, piemēram, ka noziedzīga nodarījuma priekšmets nemaz nav noziedzīgs?

\section{Mantas konfiskācija}

Mantas konfiskācijas jautājumiem pēdējos gados ir veltìts pietiekami daudz publikāciju, ir veikts pat padzịlināts pētỉjums. ${ }^{2}$ Tāpēc šeit sniegšu tikai īsu situācijas skaidrojumu, lai būtu izprotams "spēles laukums". Pirmkārt, analizēta tiks tikai noziedzīgi iegūtas mantas konfiskācija jeb, kā noteikts Krimināllikumā, mantas īpašā konfiskācija. Otrkārt, jāievēro, ka ar konfiskāciju saprotama attiecīgās mantas piespiedu bezatlīdzības atsavināšana valsts īpašumā ${ }^{-3}$. Netiks skarti jautājumi par mantas atdošanu īpašniekam. Vienlaikus pievērsǐšu uzmanību, ka visi ar noziedzīgi iegūtas mantas konfiskāciju saistītie jautājumi kopš 2017. gada 1. augusta ir regulēti Krimināllikumā (protams, izņemot procesuālo pusi).

Jautājuma analīzei ir svarīgi izprast, kas tiesīgs lemt par mantas konfiskāciju un kurā kriminālprocesa brīdī.

Klasiskā jeb visiem saprotamā situācija ir, ja lēmumu par mantas konfiskāciju pieñem tiesa galīgajā nolēmumā krimināllietā (izskatot lietu pēc būtîbas, kas ietver personas vainas konstatēěanu). Mūsdienās, ñemot vērā prokuroru kompetences paplašināšanu tiesu darba atslogošanas interesēs, arī prokurors lēmumā, ar kuru tiek pabeigts kriminālprocess, var noteikt noziedzīgi iegūtas mantas konfiskāciju, ja vien šì manta nav tāda, uz kuru tiesības reǵistrējamas publiskajā reg̣istrā (KPL 358. panta otrā daļa). Precizitātes labad būtu jāpiebilst, ka šie tiesas vai prokurora nolēmumi būs personu nereabilitējoši, jo nebūtu log̣iski un tiesiski atzìt mantu par noziedzīgi iegūtu un to konfiscēt, ja procesa rezultātā neviena persona netiktu atzīta par vainīgu noziedzīga nodarījuma izdarīšanā.

Likumā ieklautas tiesību normas, kas izriet no Eiropas Parlamenta un Padomes Direktīvas (ES) 2016/343 (2016. gada 9. marts) par to, lai nostiprinātu konkrētus nevainīguma prezumpcijas aspektus un tiesības piedalìties klātienē lietas izskatîšanā tiesā kriminālprocesā.

2 Meikališa Ā., Strada-Rozenberga K. Mantas konfiskācijas tiesiskais regulējums Latvijā un Eiropas Savienībā, tās izpildes mehānisma efektivitātes nodrošināšana. Pētijums. 2010. Pieejams: https:// www.tm.gov.lv/lv/nozares-politika/petijumi [aplūkots 2019. gada 1. maijā]].

${ }^{3}$ Krimināllikuma $70 .{ }^{10}$ pants. 
Arī pārējos gadījumos, kad kriminālprocess tiek izbeigts uz personu nereabilitējoša pamata, procesa virzitājam (izmeklētājam ar uzraugošā prokurora piekrišanu vai prokuroram) ir tiesības izdalìt no krimināllietas materiālus par noziedzịgi iegūtu mantu un uzsākt sevišķo procesu, proti, nodot šos materiālus izlemšanai tiesai KPL 59. nodaļas kārtībā (KPL 626. panta otrā un trešã daļa).

Par mantas konfiskāciju šādā procesā diskusiju parasti nav.

Taču likums jau no paša sākuma ir paredzējis iespēju konfiskācijas lēmumu pieņemt krietni agrāk - jau pirmstiesas procesa laikā KPL 59. nodalas kārtībā. Šeit nepieciešams uzsvērt, ka minētā nodala tapa tikai ekonomisko apsvērumu dēl - lai nebūtu ilgstoši jāglabā arestēta manta, par kuras noziedzīgo izcelsmi nav šaubu. Tātad ir jābūt pārliecinošiem pierādījumiem. Uz to nepārprotami norāda 626. pantā izvirzītais nosacijums: "Pierādijumu kopums dod pamatu uzskatīt, ka manta, kura izṇemta vai kurai uzlikts arests, ir noziedzīgi iegūta vai saistìta ar noziedzīgu nodarījumu”.

Tikai pēdējos pāris gados, lai atvieglotu pierādīšanas pienākumu (iespējams, apzinoties nespēju profesionāli pierādīt) un vienlaikus arī lai padarìtu efektīiāku cīṇu pret naudas atmazgāšanu, grozīts KPL 124. pants, kura sestā dala paredz: "Pierādišanas priekšmetā ietilpstošie apstākḷi attiecỉbā uz mantas noziedzīgo izcelsmi uzskatāmi par pierādītiem, ja pierādīšanas gaitā ir pamats atzīt, ka mantai, visticamāk, ir noziedzīga, nevis likumiga izcelsme."

Tomēr būtu jāuzmanās ar pazeminātā pierādīšanas sliekšnna "visticamāk" plašu piemērošanu, it îpaši pirmstiesas procesa laikā, kad personas vaina nemaz nav pierādìta. Kā jau tika uzsvērts, 59. nodaļa dod iespēju konfiscēt mantu, par kuras noziedzīgo izcelsmi nav šaubu (šajā brīdī nav pat būtiski, kas izdarījis pašu noziegumu). Klasiskais piemērs: atverot preču konteineru, tiek konstatēts, ka dokumentos norādìtā tualetes papīra vietā konteinerā atrodas cigaretes. Vai mūsdienu praksē biežāk sastopamais piemērs: nodokḷu krāpšanā iesaistìtās firmas oficiālais īpašnieks atzīst, ka firma dibināta fiktīvi un kontā esošã nauda viņam nepieder.

No tiesiskā viedokḷa, būtu visai dīvaina tiesas rīcỉba, ja tā atzītu mantu par "visticamāk" noziedzịgi iegūtu un to konfiscētu tādā procesa stadijā, kad vēl nav konstatēts, vai vispār noziegums ir noticis un vai to ir izdarijusi konkrētā persona. Tiesa šajā procesā nepārbauda pierādījumus par personas vainu. Lìdz ar to tiesa nedrìkstētu savā lēmumā paust pārliecību, ka manta, visticamāk, ir iegūta tādu noziedzīgo darbību rezultātā, kuras pastrādājusi konkrēta persona (bieži vien - šis mantas ìpašnieks), ja par šìm darbībām vēl nav ticis pieṇemts nereabilitējošs nolēmums.

Aktualitāti akcentē ne tikai starptautiskais un politiskais spiediens parādīt reālus rezultātus naudas atmazgāšanas apkarošanā, bet arī tendence sajaukt procesuālo principu piemērošanu dažǎdos procesos jeb attiecināšanu uz dažādām situācijām.

Piemēram, ilgu gadu laikā ir izdevies pārliecināt šaubīgos, ka procesā par noziedzīgi iegūtu mantu netiek aizskarts nevainīguma prezumpcijas princips. Likums prasa pierādījumu esamību, ka manta nepārprotami ir noziedzīgi radusies. Taču, ja kāda persona apgalvo, ka manta ir tās tiesiski iegūts īpašums, personai ir tiesỉbas to attiecīgi pierādìt. Šeit netiek risināts jautājums par kāda vainu noziedzīgā nodarījumā. Šì prasība vismaz lïdz šim bija loti skaidra. 
Problēma rodas tad, ja personas tiesības padara par pienākumu un to pārceḷ uz kriminālprocesu (pamatprocesu). Vēl lielāka "tiesiskuma halucinācija” var rasties, ja tam klāt piejauc mantas noziedzīgās izcelsmes prezumēšanas iespēju (Krimināllikuma 70. ${ }^{11}$ panta otrā daḷa), turklāt neatkarīgi no mantas iegādāšanās brǐža.

Kā piemēru varētu minēt kādu lietu, kurā jau ir stājies spēkā arī apgabaltiesas lēmums ${ }^{4}$. Persona S. bija izdarījusi dažādus noziegumus citā valstī un par to arī tur tikusi notiesāta. Iespējamā noziedzīgi iegūto līdzekḷu legalizācija notikusi Latvijas finanšu sistēmā, par ko uzsākts kriminālprocess Latvijā. Šajā kriminālprocesā uzlikts arests ar kriminālprocesu saistītai mantai. Policijas izmeklētājs ar lēmumu uzsācis arī procesu par noziedzīgi iegūtu mantu, apgalvojot, ka lìdzekḷi, kuriem uzlikts arests, ir iegūti ārvalstī izdarītā noziegumā un tie būtu konfiscējami. Rajona tiesas tiesnese izbeidza procesu par noziedzīgi iegūtu mantu, norādot daudzus, manuprāt, visai nopietnus argumentus. Savukārt apgabaltiesa visus šos argumentus noraidija. Tiesu nemulsināja fakts, ka ārvalstī persona S. jau bija notiesāta par šo noziedzīgi iegūto līdzekḷu legalizāciju un Latvijā uzsāktais process varētu būt ne bis in idem principa pārkāpums (diemžēl Latvijā tagad praksē nereti apzināti pārkāpj šo principu, lai jaunā procesā varētu lemt par mantas konfiskāciju, un šeit cilvēktiesību pārkāpumu nesaskata arī prokuratūra). Tiesa nav arī vērtējusi, vai personai ārvalstī jau nav tikusi piemērota (un varbūt pat izpildìta) mantas konfiskācija. Taču būtiskākais - tiesai šḳita pārliecinoši izmeklētāja sniegtie apgalvojumi, ka visi personas $S$. kontos esošie līdzekḷi un viņam piederošie nekustamie īpašumi, visticamāk, ir iegūti ārvalstī veiktajos noziegumos. Tiesas lēmumā ir minēti fakti par kontos esošo līdzekḷu izmantošanu, proti, iespējamo legalizāciju, bet nav minēts un vērtēts neviens pierādījums, kas saistītu konfiscēto mantu ar iespējamajiem predikatīvajiem noziegumiem.

Kādā citā lietā ${ }^{5}$ rajona tiesa konstatēja, ka izmeklēšanas laikā nav iegūti ticami pierādījumi tam, ka persona, kura tiek turēta aizdomās par tādu noziegumu izdarī̌sanu, kas pēc sava rakstura ir vērsti uz materiāla vai citāda labuma gūšanu, kratîšanas laikā izṇemtos naudas lìdzekḷus būtu ieguvusi likumīgā ceḷā, tāpēc šos lìdzekḷus atzina par noziedzīgi iegūtiem un nolēma konfiscēt. Apgabaltiesa vēl papildināja, ka procesā iegūtie pierādījumi dod pamatu secinājumam, ka personas finanšu līdzekḷu izlietojums pārsniedz viņas finanšu līdzekḷu ieguves avotu apjomu, tātad persona ir guvusi nelegālas izcelsmes ienākumus, turklāt persona nav arī pierādỉjusi attiecīgās mantas izcelsmes likumỉbu.

Tātad praksē sāk izplatīties tendence KPL 59. nodalas normas tulkot ne tā, kā to likums bija un ir paredzējis. Proti, galvenais vairs nav pierādījumi, ka konkrētā manta neapstrīdami ir noziedzīgi iegūta, bet pierādīšana "no pretējā" - ka šo mantu persona noteikti nevarēja iegūt legāli.

Dažos gadījumos šādu pieeju varētu piel̦aut, ja noziedzīgs nodarījums nepārprotami ir saistìts ar konkrētas mantas iegūšanu (piemēram, fiksējot konkrētu kukuḷa nodošanas / pieņemšanas faktu, atrodot apgrozībā aizliegtu vai stingri reglamentētu preču ražotni). Taču arī tad primārajam vajadzētu būt pierādījumu kopumam, ka šì

4 Tiesas 2018. gada 5. jūnija lēmums lietā ar arhīva Nr. KA04-0614-18/23 (nav publicēts).

5 Tiesas 2018. gada 5. novembra un 2019. gada 15. janvāra lēmumi krimināllietā Nr. 11816003117 (nav publicēts). 
manta ir noziedzīgi iegūta (ar noziegumu saistīta). Bet pēdējā piemērā ir vēl viena juridiski ļoti apšaubāma lieta: pamatojumā ir ietverta norāde uz nozieguma raksturu, un tas iezīmē tiesas izpratni, ka 59. nodaļas kārtībā varētu konfiscēt prezumēto noziedzīgi iegūto mantu (pirmstiesas procesa laikā tas būtu pilnīgi nepiel̦aujami).

\section{Nevainiguma prezumpcija}

Kā jau tika norādīts, mantas konfiskācijas jautājumu dažkārt nepamatoti sasaista ar nevainīguma prezumpcijas principu, bet citkārt šo "nesasaistǐšanu" cenšas attiecināt arī uz pamata kriminālprocesu, ja tajā tiek risināti mantiskie jautājumi.

Nevainīguma prezumpcijas principa saturs no dažādiem aspektiem ir atklāts neskaitāmos rakstos, pētījumos un tiesu spriedumos. Tas ir nostiprināts gan starptautiskos cilvēktiesību dokumentos ${ }^{6}$, gan Latvijas Republikas Satversmes 92. pantā, gan Kriminālprocesa likuma 19. pantā.

Tātad nav strīdu, ka tas ir fundamentāls cilvēktiesību princips un ietver trīs būtiskas atziņas: 1) personu nevar uzskatìt par vainīgu, kamēr tās vaina nav konstatēta likumā noteiktajā kārtībā, 2) personai nav jāpierāda savs nevainīgums, 3) visas šaubas jāvērtē par labu personai. Tomēr principa saturs ir krietni sarežgitāks, jo katrs virziens ir saistīts ar vairākām garantijām.

Lai gan būtiskajos aspektos principa definējums pasaulē it kā ir līdzīgs, tomēr pat Eiropas valstīs izpratne par saturu nav vienāda. Tāpēc 2016. gada 9. martā Eiropas Parlaments un Padome pieñēma Direktīvu 2016/343 par to, lai nostiprinātu konkrētus nevainīguma prezumpcijas aspektus un tiesības piedalīties klātienē lietas izskatīšanā tiesā kriminālprocesā. Direktīva konkretizē četrus ar prezumpcijas ievērošanu saistītos aspektus:

1) ne valsts iestādēm (amatpersonām), ne tiesām nav tiesības sniegt publiskas norādes par personas vainu, kamēr tā nav pierādīta (piemēram, 5. pants prasa nodrošināt, lai aizdomās turētie vai apsūdzētie - nedz tiesā, nedz sabiedrībā netiktu parādīti kā vainīgi, izmantojot fizisko brīvību ierobežojošus līdzekḷus);

2) pienākums pierādīt personas vainu ir apsūdzības izvirzītājam, apsūdzētajai personai nav jāpierāda savs nevainīgums, turklāt šaubas ir jātulko par labu aizdomās turētajai vai apsūdzētajai personai;

3) īpaši tiek aizsargātas personas tiesības klusēt un sevi neapsūdzēt, turklāt šo tiesību izmantošanu nedrīkst vērst pret aizdomās turētām un apsūdzētām personām nolūkā panākt notiesājošu spriedumu;

4) lai garantētu godīgu tiesas procesu, būtiskas ir tiesības piedalīties klātienē lietas izskatǐšanā tiesā.

Šajā rakstā īpašu uzmanību vēlētos pievērst trešajam aspektam - tiesībām klusēt, kas dažkārt tiek analizēts arī kā tiesību uz aizstāvību satura elements.

1948. gada 10. decembra ANO Vispārējās cilvēktiesību deklarācijas 11. pants, 1950. gada 4. novembra Eiropas Padomes Cilvēktiesību un pamatbrīvibu aizsardzības konvencijas 6. pants, Eiropas Savienības Pamattiesỉbu hartas 48. panta 1. punkts, ANO Starptautiskā pakta par pilsoniskajām un politiskajām tiesībām 14. pants. 
Tiesības neliecināt pret sevi ir būtisks nevainīguma prezumpcijas aspekts. Aicinot aizdomās turēto vai apsūdzēto izteikties vai atbildēt uz jautājumiem, viṇu nedrīkstētu piespiest sniegt pierādījumus, dokumentus vai informāciju, kas varētu novest pie tā, ka persona liecina pret sevi (šì prasība gan nav attiecināma uz jautājumiem par personas identifikāciju). Kā norādīts Direktīvas preambulas 28. apsvērumā un 7. pantā, klusēšana nebūtu jāvērš pret aizdomās turēto un nebūtu jāuzskata par pierādijjumu tam, ka attiecīgā persona ir izdarījusi konkrēto noziedzīgo nodarījumu.

Saistībā ar šo skaidrojumu būtu jāvērtē, vai personas klusēšana par mantas izcelsmi varētu novest pie šai personai nelabvēlīga nolēmuma.

Procesā par noziedzīgi iegūtu mantu galvenais noskaidrojamais jautājums ir: vai konkrētā manta ir noziedzīgi iegūta vai ar noziedzīgo nodarījumu saistīta. Tiesai nav jānoskaidro un izmeklētājam vai prokuroram nav jāpierāda, kurš ir izdarījis noziedzīgo nodarījumu, kas "radijja” šo mantu. Personas vaina netiek skaidrota, lìdz ar to nedarbojas arī nevainīguma prezumpcijas princips. Persona, kura uzskata, ka tai ir legālas tiesības uz šo mantu, ir tiesīga savas tiesības aizstāvēt. Tā būs viñas civilo tiesību pamatošana. Protams, ikviena aizskartā persona jautājumā par mantas izcelsmi un piederību var arī klusēt, bet tas nekādā gadījumā nedos pamatu secinājumam, ka šì persona ir izdarījusi noziedzīgu nodarījumu.

Taču jāatceras, ka šis process tomēr nerodas no zila gaisa, proti, likums prasa vispirms iegūt pierādījumu kopumu par mantas noziedzīgo izcelsmi. Ar kriminālprocesa metodēm nedrīkstētu risināt atrastas mantas piederības jautājumus vai personas ienākumu (mantas izcelsmes) legalitāti. Atcerēsimies, ka ne jau mantas (pat neskaidras izcelsmes mantas) esamība rada pamatu kriminālprocesa uzsākšanai. Kriminālprocesa pamats ir ziņas par noziedzīga nodarījuma notikumu, nevis ziņas par mantas atrašanu.

Pilnīgi atšķirīga situācija būtu kriminālprocesā, kurš uzsākts par iespējamu noziedzīgi iegūtu līdzekḷu legalizācijas faktu. Šajā procesā galvenais noskaidrojamais jautājums ir: kurš to izdarijja jeb, citiem vārdiem sakot, kurš ir vainīgs legalizācijā. Turklāt šeit vairs pat nevajadzētu būt diskusijai, vai legalizēta tiek noziedzīgi iegūta manta. Tam būtu jābūt pierādìtam un konstatētam vai nu kādā agrākā kriminālprocesā, vai procesā kopā ar legalizāciju, tikai “pirms piecām minūtēm”. Nevarētu taču uzskatīt par log̣isku un arī tiesisku spriedumu, ar kuru persona tiktu atzīta par vainīgu tādu līdzekḷu legalizācijā, kuri varbūt pat nav noziedzīgi.

Saistībā ar šo procesu personai, kuru tur aizdomās par legalizāciju, nevarētu rasties pienākums izskaidrot tās mantas izcelsmi, ar kuru ir veiktas "legalizācijas” darbības. Daži praktiksi uzskata, ka manta ir noziedzịga nodarijuma priekšmets (neietilpst noziedzīgā nodarījuma sastāvā) un tāpēc ir iespējams ar minimāliem pierādījumiem izvirzìt prezumpciju par tās izcelsmi, kura tad būtu jāatspēko aizdomās turētajam.

Taču legalizācija kā noziegums nemaz nepastāvētu, ja manta nebūtu noziedzīga. Uzdodot jautājumu par mantas izcelsmi, pēc būtības tiek uzdots jautājums: vai jūs izdarījāt šo noziegumu.

Iedomājieties situāciju, kurā persona par saviem bankas kontā esošajiem līdzekliem iegādājas nekustamo īpašumu. Kādai amatpersonai šķiet, ka šī persona nevarētu tik labi dzīvot. Tiesiskā valstī situāciju noskaidrotu Valsts ieņēmumu dienests, kas varbūt pat uzrēḳinātu nodokli par nedeklarētiem ienākumiem un piemērotu soda naudu. 
Taču amatpersonai nepatīk konkrētā persona (politiskais pretinieks, nesimpātisks oligarhs), tāpēc izmanto "smagāku artilēriju”, proti, tieši vai pastarpināti panāk kriminālprocesa uzsākšanu par noziedzịgi iegūtu līdzekḷu legalizāciju. Izmeklēšanas laikā neizdodas pierādīt naudas noziedzīgo izcelsmi, bet to prasa izskaidrot īpašniekam, kurš izmanto tiesības paklusēt. Ja likums uzliktu pienākumu runāt, varētu būt vairāki scenāriji: 1) naudas legālā izcelsme tiešām tiek pierādīta, 2) nauda nopelnīta, pārkāpjot likumu, taču ne noziedzīgi, 3) tālā zemē esoša drauga naudas dāvinājums (par melošanu aizdomās turēto pie atbildības saukt nevar), 4) tā tiešām iegūta noziedzīgi. Otrajā un ceturtajā gadỉjumā persona ir bijusi spiesta liecināt pret sevi. Tas būtu vistiešākais nevainīguma prezumpcijas pārkāpums (starp citu, šis princips vienlīdz darbojas arī administratīvo pārkāpumu procesā). Atsakoties sniegt skaidrojumu, tiktu prezumēts, ka manta ir noziedzīga. Tādējādi iznāktu, ka visos gadījumos, kad persona nespētu izskaidrot mantas legālo izcelsmi vai nevēlētos to izskaidrot, tā tiktu atzīta par vainīgu. No tā izriet secinājums, ka šāda prasība novestu pie pienākuma pierādìt savu nevainīgumu, kas ir rupjš nevainīguma prezumpcijas principa pārkāpums.

Šāds risinājums, kas šobrīd gan ir tikai likumprojekta līmenī, ir mēgeinājums risināt izmeklēšanas kvalitātes problēmu. Mēǵginājums, kas var novest pie cilvēktiesību pārkāpuma likumu līmenī. Argumentācijā, uz kā balstās konkrētais projekts, tiek sajaukts kopā process par personas vainu ar attiecībām, kādas pastāv sevišķajā procesā par noziedzīgi iegūtu mantu?

Skaidrojot nevainīguma prezumpcijas vienu nelielu aspektu - tiesības klusēt -, nevarēja izvairīties no pierādīšanas pienākuma pieminēšanas. Ja nav tiesību klusēt, rodas pienākums runāt. Tāpēc svarīgi noskaidrot, kam ir šis pienākums runāt un cik pārliecinošai šai runai jābūt.

\section{Pierādišanas pienākums}

Protams, nevainīguma prezumpcija, tostarp tiesības klusēt un neliecināt pret sevi, nav absolūtas. Noteiktos gadijumos likumdevējam ir tiesības likuma normās paredzēt tā saukto legālo prezumpciju - atspēkojamu prezumpciju par faktiskajiem apstākḷiem, kas norāda uz personas vainu vai atbildību. ${ }^{7}$ Šādus apstākḷus mēs redzam Kriminālprocesa likuma 125. pantā, kas saprātīgi domājošam cilvēkam nerada šaubas, ka nav nepieciešams pierādīt logiski izsecināmus pieṇēmumus.

Taču šā raksta kontekstā dažkārt tiek norādīts uz KPL 125. panta otro daļu, kurā arī tiekot prezumēta personas vaina, ja vien netiek pierādìts pretējais. Norma nosaka: "Ir uzskatāms par pierādītu, ka persona ir pārkāpusi tiesiskā īpašnieka autortiesības, blakustiesības vai tiesības uz preču zìmi, ja vien tā nespēj ticami izskaidrot vai pamatot šo tiesību iegūšanu vai izcelsmi." Daḷēji tam var piekrist, tomēr ir viena būtiska atškirīiba. Proti, normā ir minēta prezumpcija, kas ìstenībā ir pastāvējusi gadu desmitiem un ne tikai Latvijā, tikai ne tiešā tekstā likumā ierakstīta: personai pašai ir jāspēj pierādīt tiesības lietot kādas īpašā procesā iegūstamas tiesības, jo valstij būtu visai apgrūtinoši pierādīt fakta neesamību (ir tikai loğiski, ka var prasīt pierādīt pozitīvo faktu jeb fakta

7 Satversmes tiesas 2016. gada 15. novembra spriedums lietā Nr. 2015-25-01, 19. punkts. 
esamību). Piemēram, tiesības nēsāt ieroci, tiesības lietot narkotiskās vielas, tiesības atrasties cita īpašumā, arī tiesības izmantot citas personas autortiesības.

Tiesības uz sev piederošu mantu personai nav jāpierāda, ja vien kāds nav izteicis apgalvojumu un iesniedzis tā pierādījumus, ka šì manta šim cilvēkam nepieder. Tas attiecas arī uz iespējami noziedzīgo mantu - valstij ir jāizvirza pietiekami pamatoti argumenti, kāpēc manta būtu uzskatāma par noziedzīgi iegūtu. Tikai pēc tam seko personas tiesības runāt vai klusēt (taču ne pienākums).

Arī Eiropas Cilvēktiesību tiesa (turpmāk ECT) vairākos spriedumos ir atzinusi, ka kriminālprocesā ir piel̦aujama fakta prezumēšana, tikai jāṇem vērā, kas tiek prezumēts, un jāpārliecinās, vai prezumpcija ir saprātīgi atspēkojama. ${ }^{8}$

Aplūkojamās problēmas kontekstā vērtīgas atziņas sniegtas ECT spriedumā lietā Zschüschen v. Belgium. ${ }^{9}$ Lietas būtỉba: Nĩderlandes pilsonis C. Beḷgijas bankā atvēra kontu un piecās reizēs tajā iemaksāja 75000 eiro. Pēc bankas sniegtã ziṇojuma tika sākts kriminālprocess par naudas atmazgāšanu. Sākotnēji C. naudas gūšanu izskaidroja ar nedeklarētu darbu, nenorādot darba devēju, taču pēc tam izmantoja tiesības klusēt. Krimināltiesa piesprieda 10 mēnešu cietumsodu, 5000 eiro naudas sodu, kā arī konfiscēja 75000 eiro. C. uzskatija, ka ir pārkāptas viṇa tiesības tikt uzskatītam par nevainīgu, tiesỉbas klusēt un tiesības uz aizstāvību.

ECT nekonstatēja Konvencijas pārkāpumus, jo tiesa secināja, ka notiesājošais spriedums noteikti nebalstijjās tikai vai būtỉbā uz personas klusēšanu. Vietējās tiesas bija guvušas pārliecinošu pierādījumu kopumu par naudas izcelsmi (Nìderlandē reǵistrēti vairāki ar narkotikām saistīti pārkāpumi, citu legālu ienākumu avotu neesamība), tāpēc C. atteikšanās sniegt paskaidrojumus par naudas izcelsmi tikai apstiprināja šos pierādījumus. Taču tiesa arī atkārtoti norādīja, ka ar taisnīgas krimināltiesas jēdzienu nebūtu savienojama prasība personai uzlikt pienākumu sniegt paskaidrojumu par saviem īpašumiem. Papildus gan jāatzīst, ka šajā lietā ECT vairākkārt atsaucās uz valsts judikatūras prasībām, kas paredz visu aizdomigo darījumu visaptverošu un detalizētu aprakstu, kāa arī faktu juridisko raksturojumu, kas bija pieejams personai.

Arī no šīs lietas var konstatēt, ka likums (un starptautiskie cilvēktiesỉbu dokumenti) neliedz aicināt aizdomās turēto personu sniegt skaidrojumu par savas mantas izcelsmi. Klusēšana vai melošana tāpat var tikt izmantota par pierādījumu vai, drīzāk, par citu pierādījumu ticamības apstiprinājumu (palīgfakts). Taču notiesāšanai ir nepieciešams gūt pārliecinošus pierādījumus par naudas izcelsmi. Lai arī Beḷgijas likumi neprasa obligātu notiesāšanu par predikatîvo noziegumu, naudas "visticamāk" iegūšana no noziedzīgās darbības ir jāpierāda.

Latvijas likumos ir noteikts, ka pierādǐšanas pienākums kriminālprocesā pirmstiesas procesa laikā ir procesa virzìtājam (izmeklētājam vai prokuroram), bet iztiesāšanā apsūdzības uzturētājam (prokuroram). Tas attiecas uz pienākumu pierādīt noziedzīgā nodarijuma sastāvu.

Eiropas Cilvēktiesību tiesas 1988. gada 7. oktobra spriedums lietā Salabiaku v. France, pieteikums Nr. 10519/83, 26.-28. punkts.

9 Eiropas Cilvēktiesību tiesas 2017. gada 2. maija spriedums lietā Zschüschen v. Belgium, pieteikums Nr. 23572/07. 
Kā jau tika minēts, ar likumu var tikt prezumēti konkrēti fakti, un personai ir tiesības tiem nepiekrist, bet šāda apgalvojuma gadijjumā personai arī rodas pienākums vismaz norādìt uz pierādījumiem par fakta neatbilstību îstenībai (KPL 126. panta trešā daļa).

Arī Krimināllikuma 70. ${ }^{11}$ panta otrā daļa ietver prezumpciju, proti, par noziedzīgi iegūtu var atzìt mantu, kas pieder personai, kura izdarijusi vai ir saistīta ar noteikta rakstura noziegumiem, ja personai piederošā manta nav samērīga ar personas likumīgiem ienākumiem un ja persona nepierāda, ka manta iegūta likumīgā cel̦ā. Lai gan šì prezumpcija nav par personas vainu, bet tajā skaidri definēts katras puses pienākums. Valstij jāpierāda personas saistība ar likumā norādìtu noziedzīgu darbību un tas, ka valstij zināmie personas likumīgie ienākumi acīmredzami nedotu iespēju iegādāties tādas vērtības mantu. Pēc tam persona var nepiekrist mantas izcelsmes prezumpcijai, bet tad tai rodas pienākums savus apgalvojumus arī pierādīt.

Aplūkotā pierādīšanas pienākumu izpildes secība jeb pierādīšanas nastas pārlikšana ir izmantojama kriminālprocesā, lemjot par personas vainu. Nenoliedzami sākotnēji tieši procesa virzītājam ir jāsniedz pierādỉjumi par to, ka manta, visticamāk, ir noziedzīgi iegūta, valstij pirmajai ir jānorāda uz esošajiem pierādījumiem. Tikai tad persona, kurai ir tiesības uz aizstāvību, var izvēlēties savu aizstāvības pozīciju. Atcerēsimies, ka katrai personai, par kuru izteikts pien,ēmums vai apgalvojums, ka tā izdarỉjusi noziedzīgu nodarījumu, ir tiesības zināt, kāda nodarījuma izdarīšanā to tur aizdomās vai apsūdz (tas precīzi tika nodrošināts aplūkotajā Beḷgijas krimināltiesas lietā).

Tas saskan ar Eiropas Padomes 2005. gada 16. maija Konvencijas par noziedzīgi iegūtu līdzekḷu legalizācijas un terorisma finansēšanas novēršanu, kā arī šo līdzekḷlu meklēšanu, izṇemšanu un konfiskāciju 9. panta sesto daḷu, kurā ir precīzi norādīts: "Ikviena dalỉbvalsts nodrošina to, ka saskaņā ar šo pantu personu var notiesāt par noziedzīgi iegūtu līdzekḷu legalizāciju, ja ir pierādīts, ka šā panta 1. punkta a) vai b) apakšpunktā norādītais īpašums ir iegūts, izdarot predikativu nodarijumu, turklāt šādā gadỉjumā nav precīzi jāpierāda, ar kuru noziegumu ir saistīta šāda īpašuma ieguve.”

Arī jaunajā Eiropas Parlamenta un Padomes Direktīvā 2018/1673 par nelikumīgi iegūtu līdzekḷu legalizācijas apkarošanu ar krimināltiesībām (jāievieš līdz 2020. gada 3. decembrim) paredzētā notiesāšanas iespējamība (notiesāšana par legalizāciju arī bez iepriekšēja vai vienlaicīga notiesājoša sprieduma par noziedzīgu darbību, kurā iegūts īpašums) ir saistīta ar prasību "ja ir konstatēts, ka īpašums ir bijis iegūts noziedzīgā darbībā, neprasot precīzi konstatēt visus faktiskos elementus vai visus apstākḷus saistībā ar minēto noziedzīgo darbību, tostarp izdarītāja identitāti” (3. panta trešās daļas "b" punkts).

Minētie secinājumi nerunā pretī arī Finanšu darījumu darba grupas (FATF) trešās rekomendācijas (konkrētāk, tās ceturtās skaidrojošās piezīmes) izpildei, proti, nodrošināt valsts spēju panākt notiesājošu spriedumu par noziedzīgi iegūtu līdzekḷu legalizēšanu bez iepriekšējas notiesāšanas par predikatīvo noziegumu (stand alone). Rekomendācijā uzsvērti divi aspekti: 1) legalizācija saistāma ar jebkuru vērtību, kas tieši vai netieši uzskatāma par noziedzīgi iegūtiem līdzekḷiem, 2) pierādot, ka attiecīgā manta ir noziedzīgi iegūti lìdzekḷi, personai nav jābūt notiesātai par predikatīvo nodarījumu. 
Tas nozīmē, ka procesa virzītājam ir jāpamato izvirzìtais pieṇēmums par noziedzīgi iegūtas mantas legalizēšanu vismaz ar sākotnējiem pierādījumiem par personas darbībām ar, iespējams, noziedzīgu mantu. Taču tāpat ir jāpierāda mantas noziedzīgā izcelsme, lai arī persona netiek notiesāta par šo predikatīvo nodarījumu. Iespējams, šeit varētu palīdzēt mantas prezumēšana par noziedzīgi iegūtu (un Krimināllikuma 70. ${ }^{11}$ pants sniedz precīzu definējumu, ar kādiem nosacijumiem mantu drīkst atzìt par noziedzīgi iegūtu).

Ja mantas noziedzīgā izcelsme tiek prezumēta, svarīgi ir pierādīt subjektīvo pusi, proti, vai persona vismaz apzināti piẹ̦āva, ka manta ir noziedzīga. No cilvēktiesību viedokḷa nav piel̦aujama dubultā prezumpcija - vispirms pien,em, ka manta ir noziedzīga (tas netiek pierādīts atbilstoši kriminālprocesa standartiem), un pēc tam prezumē, ka personai vajadzēja apzināties, ka manta ir noziedzīga (respektīvi, ka valsts prezumēs, ka tā tas ir). Ja šādos gadījumos personas vaina noziedzīgā nodarījumā netiek pierādīta, bet apsūdzība balstās tikai uz personas nevēlēšanos vai nespēju pierādìt mantas izcelsmi, tas būtu vērtējams kā nevainīguma prezumpcijas pārkāpums.

Nav īpašu diskusiju par to, ka kriminālprocesā var konfiscēt īpašumu, ja ir pierādīta personas vaina nozieguma izdarǐšanā un ir pietiekami pierādijjumi, kas novērš šaubas, ka manta iegūta noziedzīgā ceḷā. Šādos procesos ir būtiski, vai mantas īpašniekam, kas pats pat nav vainīgs nozieguma izdarī̌̌anā, ir bijusi nodrošināta iespēja piedalīties procesā un aizstāvēt savas intereses. ${ }^{10}$ Tāpat tiek vērtēts, vai konfiscētās mantas apjoms nav būtiski disproporcionāls kriminālprocesā pierādītā noziedzīgi iegūtā labuma apmēriem. ${ }^{11}$

Nedaudz jaunas vēsmas ECT praksē vērojamas pēdējos gados, kad īpaši tiek pastiprināta cīṇa pret korupciju un noziedzīgi iegūto līdzekḷu legalizāciju. Starptautiskās organizācijas - FATF, GRECO, MONEYVAL, Ekonomiskās sadarbības un attīstības organizācija (OECD) - savos izvērtēšanas ziņojumos pieprasa vai rekomendē valstīm izstrādāt tādus noziedzīgi iegūtas mantas konfiskācijas pasākumus, kas nebūtu saistīti ar vainīgās personas obligātu iepriekšēju notiesāšanu. Dažādās valstīs ir dažādi risinājumi, tiek ieviesta arī tā sauktā civiltiesiskā (dažkārt sauc arī par administratīvo) konfiskācija.

Piemēram, ECT savā spriedumā lietā Gogitidze un citi pret Gruziju ${ }^{12}$ vērtēja Gruzijas likumos kopš 2004. gada 13. februāra ietvertās normas, kas paredzēja: ja pastāv pamatotas aizdomas, ka īpašums radies no valsts amatpersonas nelikumīgām darbībām, prokurors var celt prasību tiesā par šì īpašuma konfiskāciju (Kriminālprocesa kodeksa 37. panta 1. daļa). Šādu prasību izskata civiltiesiskā kārtībā (Administratīvā procesa kodeksa 21. panta 5.un 6. daḷa), un kriminālā notiesāšana nav priekšnoteikums konfiskācijas procesam, taču apsūdzībai jābūt uzrādītai, un tai jābūt par likuma

10 Sk., piemēram, Eiropas Cilvēktiesību tiesas 2012. gada 10. aprīḷa spriedumu lietā Silickiene v. Lithuania, pieteikums Nr. 20496/02. Konfiscēts apsūdzētā atraitnes īpašums, kura zināja par tā izcelsmi. Konvencijas Pirmā protokola 1. panta pārkāpums netika konstatēts.

11 Sk., piemēram, Eiropas Cilvēktiesību tiesas 2016. gada 17. maija spriedumu lietā Džinič v. Croatia, pieteikums Nr. 38359/13. Tika konstatēts Konvencijas Pirmā protokola 1. panta pārkāpums.

12 Eiropas Cilvēktiesību tiesas 2015. gada 12. maija spriedums lietā Gogitidze and others v. Georgia, pieteikums Nr. 36862/05. 
pārkāpumiem valsts dienestā (tostarp - korupciju), vai arī par noziedzīgi iegūtu līdzekḷu legalizēšanu, izspiešanu, piesavināšanos vai izvairīšanos no nodokḷu maksāšanas.

ECT atzina, ka pastāv universālie tiesiskie standarti, kas, pirmkārt, veicina tāda īpašuma konfiskāciju, kas saistīts ar smagiem noziegumiem (korupciju, noziedzīgi iegūto līdzekḷu legalizēšanu, narkotiku pārkāpumiem), bez kriminālas notiesāšanas. Otrkārt, pienākumu pierādīt mantas likumīgu ieguvi ar likumu var pārlikt personai, kas iesaistīta šādā "nekriminālā" procesā par konfiskāciju, ieskaitot arī civilprocesu in rem. Treškārt, konfiskāciju var piemērot ne tikai tieši noziedzīgi iegūtiem līdzekḷiem, bet arī īpašumam (ienākumiem un citiem netiešiem labumiem), kas iegūti, pārvēršot vai pārveidojot noziedzīgi iegūto vai sajaucot to kopā ar likumīgiem lìdzekl̦iem. Visbeidzot, konfiskācijas pasākumus var piemērot ne tikai personai, kas tieši tiek turēta aizdomās, bet arī trešajai personai, kurai ir šīs īpašuma tiesības (ja vien tā nav labticīgs ieguvējs).

ECT nesaskatīja problēmu, ka konfiskācija notiek bez apsūdzētā vainu pierādoša notiesājoša sprieduma. Konfiskācija pamatojās uz pierādījumiem, kas liecināja, ka atbildētāju likumīgie ienākumi nebija pietiekami, lai viņi varētu šādus īpašumus iegūt. Turklāt konfiskācija tika izlemta civilprocesā in rem par ienākumiem no smagiem noziegumiem, līdz ar to tiesvedībā nebija nepieciešami pierādījumi "virs pamatotām šaubām” par īpašuma nelikumīgo izcelsmi. Pierādỉjumi tika atzìti par pietiekamiem, jo tiesas izvērtējumā tika konstatēta pārliecỉba par īpašuma nelikumīgās izcelsmes lielu iespējamību un īpašnieka nespēju pierādīt pretējo.

Lìdz ar to varētu secināt: noziedzīgi iegūtu līdzekḷu konfiskācijas iespējas mūsdienu pasaulē tiek pilnveidotas. Atšķirībā no kriminālprocesa, kurā jāievēro kriminālprocesuālie principi, valstīm ir tiesības ieviest īpašuma atsavināšanu vai konfiskāciju civilprocesuālā kārtībā. Šādā procesā in rem nav obligāta prasība par kādas personas atzīšanu par vainīgu noziedzīga nodarījuma izdarīšanā. Taču ir jābūt pierādījumiem, kas tiesai rada pārliecību, ka konfiscējamais īpašums ir iegūts no noziedzīgām darbībām. Savukārt mantas īpašniekam šajā procesā ir visas procesa dalībnieka tiesības, lai gan viṇa "pierādīšanas nastā” svarīgākais ir pierādīt šīs mantas legālo izcelsmi.

\section{Kopsavilkums}

1. Mantas konfiskāciju kriminālprocesā persona uztver l̦oti sāpīgi, jo mantiska labuma gūšana visbiežāk ir bijis noziedzīgās darbības mērḳis. Tāpēc arī starptautiskajos dokumentos pēdējos desmit gados īpaši tiek uzsvērta prasība atņemt finansējumu noziedzīgai darbībai. Turklāt rekomendācijās ierosināts mantas konfiskāciju īstenot jebkādām metodēm: ja nevar kriminālprocesa sistēmā - izmantot civilprocesu, pierādīšanas pienākumu pārliekot uz mantas īpašnieka pleciem, izmantot paplašinātās konfiskācijas iespēju.

2. Nav diskusiju, ka mantas konfiskācija kā kriminālsods tiek piemērota kriminālprocesa noslēgumā, kad personas vaina noziedzīgajā nodarījumā ir pierādīta. Līdzīga situācija ir ar noziedzīgi iegūtas mantas konfiskāciju kriminālprocesa noslēgumā, jo arī tad personas vaina un mantas noziedzīgā izcelsme tiek pierādīta. Nevainīguma prezumpcijas princips darbojas. 
3. Aktuāls ir jautājums par prezumētās noziedzīgi iegūtās mantas konfiscēšanu (paplašinātā konfiskācija), pirms personas vaina noziedzīgajā nodarījumā ir konstatēta ar galīgo nolēmumu kriminālprocesā. Papildus tam problēmu rada jēdzienu "neskaidras izcelsmes manta (finanšu līdzekḷi)" un "noziedzīgi iegūta manta" sajaukšana praksē. Vēl sarežǵitāku situāciju padara prasība, lai, pamatojoties uz prezumpciju par mantas noziedzīgo izcelsmi, tiktu sodìta persona par šìs mantas legalizāciju.

4. Tiesību normās ir norobežota mantas konfiskācija, ja tās noziedzịgā izcelsme ir pierādīta. Tāpat ir iespējams konfiscēt prezumēto noziedzīgi iegūto mantu, paplašinot kritēriju uzskaitijumu, kas l̦auj izdarīt šādu pien̦ēmumu. Valsts ir tiesīga prasìt personai pierādīt (ja tā vēlas) mantas iegūšanas veidu. Šādos procesos jautājums nav par personas vainu.

5. No cilvēktiesību viedokḷa kriminālprocesos par noziedzīgi iegūtu līdzekḷu legalizāciju nav piel̦aujama dubultā prezumpcija - par mantas noziedzīgo izcelsmi un par personas apzināšanos, ka šì manta ir noziedzịga. Ja šādos gadījumos personas vaina noziedzīgā nodarỉjumā netiek pierādìta, bet apsūdzība balstās tikai uz personas nevēlēšanos vai nespēju pierādīt mantas izcelsmi, tas ir nevainīguma prezumpcijas pārkāpums.

6. Nebūtu atbalstāma likuma grozišana ar apšaubāma satura normu, kas uzliek personai pienākumu pierādīt savas mantas izcelsmi, citādi tiks prezumēts, ka manta ir noziedzīgas izcelsmes un persona ir krimināli sodāma par šãdas mantas legalizēšanu. Tas būtu rupjš nevainīguma prezumpcijas principa pārkāpums, jo pārkāptas tiek gan tiesības klusēt un sevi neapsūdzēt, gan tas, ka personai nav jāpierāda savs nevainīgums.

\section{BIBLIOGRĀFIJA}

1. Meikališa Ā., Strada-Rozenberga K. Mantas konfiskācijas tiesiskais regulējums Latvijā un Eiropas Savienībā, tās izpildes mehānisma efektivitātes nodrošināšana. Pētījums. 2010. Pieejams: https://www.tm.gov.lv/lv/nozares-politika/petijumi [aplūkots 2019. gada 1. maijā].

\section{Likumi un normativie akti}

2. ANO Starptautiskais pakts par pilsoniskajām un politiskajām tiesībām. 1966. 16. decembris. Latvijas Vēstnesis, 2003. 23. aprïlis, Nr. 61 (2826).

3. ANO Vispārējā cilvēktiesību deklarācija, 1948. 10. decembris. Pieejams: https://www.ohchr. org/EN/UDHR/Documents/UDHR_Translations/lat.pdf

4. Eiropas Padomes Cilvēktiesību un pamatbrīvību aizsardzības konvencija, 1950. 4. novembris. Latvijas Vēstnesis, 1997. 13. jūnijs, Nr. 143/144 (858/859).

5. Eiropas Parlamenta un Padomes Direktīva (ES) 2016/343 (2016. gada 9. marts) par to, lai nostiprinātu konkrētus nevainīguma prezumpcijas aspektus un tiesības piedalīies klātienē lietas izskatī̌̌anā tiesā kriminālprocesā. Eiropas Savienības Oficiālais Vēstnesis, 2016. 11. marts. Pieejams: https://eur-lex.europa.eu/legal-content/LV/TXT/?uri=CELEX\%3A32016L0343 
6. Eiropas Savienības Pamattiesību harta. Eiropas Savienības Oficiālais Vēstnesis, 2016. 7. jūnijs, Nr. C202/389. Pieejams: https://eur-lex.europa.eu/legal-content/LV/TXT/PDF/?uri=CELEX:12016P/TXT\&from=FR

7. Krimināllikums: LV Likums. Latvijas Vēstnesis, 1998. 8. jūlijs, Nr. 199/200 (1260/1261).

8. Kriminālprocesa likums: LV Likums. Latvijas Vēstnesis, 2005. 11. maijs, Nr. 74 (3232).

9. Latvijas Republikas Satversme: LV Likums. Latvijas Vēstnesis, 1993. 1. jūlijs, Nr. 43.

10. Par likuma "Par nodokḷiem un nodevām" 60., 61. un 62. panta atbilstību Latvijas Republikas Satversmes 91. panta pirmajam teikumam, 92. pantam un 105. pantam: Latvijas Republikas Satversmes tiesas 2016. gada 15. novembra spriedums lietā Nr. 2015-25-01. Latvijas Vēstnesis, 2016. 16. novembris, Nr. 224 (5796).

\section{Tiesu prakse}

11. Eiropas Cilvēktiesību tiesas spriedums lietā: 10519/83 Salabiaku v. France.

12. Eiropas Cilvēktiesību tiesas spriedums lietā: 20496/02 Silickiene v. Lithuania.

13. Eiropas Cilvēktiesību tiesas spriedums lietā: 23572/07 Zschüschen v. Belgium.

14. Eiropas Cilvēktiesību tiesas spriedums lietā: 36862/05 Gogitidze and others v. Georgia.

15. Eiropas Cilvēktiesību tiesas spriedums lietā: $38359 / 13$ Džinič v. Croatia. 